Article

\title{
Exploring the Consumer Attitude of Building-Attached Photovoltaic Equipment Using Revised Technology Acceptance Model
}

\author{
Ruey-Chyn Tsaur *(i) and Yi-Hsuan Lin \\ Department of Management Sciences, Tamkang University, No.151, Yingzhuan Rd., Danshui Dist., \\ New Taipei City 25137, Taiwan; amy401620165@gmail.com \\ * Correspondence: rctsaur@yahoo.com.tw; Tel.: +886-2-26215656
}

Received: 16 October 2018; Accepted: 9 November 2018; Published: 13 November 2018

\begin{abstract}
Climate change affects agriculture, the water supply, health, and the sustainability of the environment, and is largely due to greenhouse gases produced by human activities and power production. In order to reduce greenhouse gas emissions, the usage of renewable green energy must be promoted. The International Energy Agency showed that renewables have surpassed coal as the largest source of installed power capacity; half a million solar panels are installed every day around the world. The Taiwanese government has planned to block its fourth nuclear power plant, and is closing Taiwan's three operating nuclear power plants since solar energy is the best way to solve power shortages. This study defined a solar-energy building as a Building-Attached Photovoltaic (BAPV) system in which the solar modules can be attached to and detached from the building without any structural damage; then, we proposed the Technology Acceptance Model (TAM) to forecast and explain public acceptance of BAPV. Last, we explored consumers' intentions to use the BAPV systems and their purchasing behavior. The analytical results are fairly consistent with the proposed hypotheses. We find that when perceived ease of use (PEOU) is the antecedent of perceived usefulness (PU) and attitude toward using (AT), the model fit shows a positive influence. However, when PEOU directly affects AT, it shows a negative influence. These two opposing results show that consumers lack an awareness of PEOU. In order to get a positive AT, PEOU and PU have to be synergized. Further, the PEOU also has a negative influence on the antecedent of AT, but positively affects purchasing behavior.
\end{abstract}

Keywords: green energy; green awareness; technology acceptance model; purchasing behavior

\section{Introduction}

With its protective atmosphere, the Earth is able to sustain and nurture life. Yet, the burning of fossil fuels by humans has caused the Earth's surface temperature to rise, worsening the already irreversible effects of global warming. As the planet gets warmer, the ice caps of both poles are melting rapidly, discharging large volumes of water into the oceans. This has led to the rising of the sea level, causing massive disruptions and destructions to coastal residents [1,2]. The reduction in livable land areas creates many climate refugees among the coastal residents [3,4], forcing them to relocate from their place of residence, temporarily or permanently. Scholars looking into climate governance have indicated that the Asia Pacific region may suffer a stronger effect from climate change due to its geographical environment and population distribution $[5,6]$. Based on these reports, the possibility of becoming climate refugees is higher in Asia than in any other region, and since Taiwan is an island surrounded by water, it is much more vulnerable to the threat. As more people are made aware of the devastation caused by climate change and the extent of resource scarcity, 
environmental issues and crises have gained massive international attention. Together with the topic of sustainable development, environmental awareness is spreading fast and wide. Countries all over the world are trying to strike a balance between economic and sustainable development. The green revolution is sweeping across the globe, and has become an important initiative in the 21st century. Governments try to adhere to the $3 R$ principles (Reduce, Reuse and Recycle) to improve resource utilization and maximize resource efficiency. Moreover, governments also seek to adapt their policies to ensure sustainable development for their national economy [7]. As a country heavily dependent on its manufacturing industry, Taiwan has long been relying on thermal power as its main source of electricity. This reliance on thermal power has led to the rising greenhouse gas emissions, as coal-fired power generation remains the cheapest and easiest power source. According to the statistical data from the Environmental Protection Administration of Taiwan, the total greenhouse gas emissions for 2014 was 284.51 million tons. Direct emission by the Taiwan Power Company was found to be as high as $37.36 \%$, making it the largest emission sector in Taiwan [8]. Thus, in order to slow the rate of global warming, it is imperative to change the method of power generation. Taiwan needs to find new means of power generation, as the use of coal, oil, or natural gases produces prodigious amounts of methane, carbon dioxide, and other waste gases. Meanwhile, hydropower generation will cause ecological damage to the biological habitat of the upper reservoir areas. Furthermore, hydropower generation is also subjected to the seasonality of rainfall. Maintaining steady power generation is paramount. Another possible source of renewable energy in Taiwan is wind power. Wind turbines require unobstructed access to strong winds, which is something quite that is difficult to find in a small island such as Taiwan. Also, those huge rotating blades could cause damage to the nearby areas, posing a huge noise hazard and harming flying animals. In addition, its generation capacity is relatively smaller than other power sources, and thus cannot be used as a base load power source. Since 1978, the Taiwanese government has been constructing nuclear power plants to meet the demand for electricity. Nevertheless, residents located in the vicinities of these nuclear power plants have had to live with the daily threat of radiations. The classic 'not in my backyard' theory [9-11] showed that a dilemma remains. If there is any radiation leakage or other unwanted incidents within these nuclear power plants, their devastating effects will be felt for many generations to come. In view of the fear and expectation of the public, the government has amended the policy of electricity generation, and forced the suspension of the fourth nuclear power plant in July 2015. The government has also agreed to decommission all of the nuclear power plants and become totally nuclear-free by the year 2025 . Without these nuclear power plants, the existing power generation will not be able to meet the demand, and will result in a higher electricity price. Thus, if the government were to ensure an sufficient power supply, the government must develop policies and/or subsidies to encourage the public to invest in renewable energy.

The International Energy Agency (IEA) defines renewable energy as being "derived from natural processes that are replenished constantly. In its various forms, it derives directly or indirectly from the sun, or from heat generated deep within the Earth. Included in the definition is energy generated from solar, wind, biomass, geothermal, hydropower, and ocean resources, and biofuels and hydrogen derived from renewable resources" [12]. These resources are inexhaustible, do not produce any contaminants, and do not require billions of years to be replenished, unlike fossil fuels. Nonetheless, huge obstacles remain in the production of renewable energy, including high development costs and a high technology threshold. These problems cannot be resolved within a short period of time; thus, we need assistance from the government to help promote and support renewable energy production. In 2012, the Bureau of Energy (BOE) of the Ministry of Economic Affairs (MOEA) has established the promotion office of the "Million Rooftop Photovoltaic Program". Other than fostering a photovoltaic-friendly environment in Taiwan, the program promotion office aimed to actively assist local governments and industries in achieving a PV installed capacity of $6200 \mathrm{MW}$ by 2030 [13]. Based on the Regulations on the Management of Renewable Energy Power Generation Equipment, the photovoltaic $(\mathrm{PV})$ power system is defined as power generation equipment that uses solar cells to 
convert solar energy [14]. From the degree of solar-energy building integration, a photovoltaic power system can be categorized as either Building-Integrated Photovoltaic (BIPV) or Building-Attached Photovoltaic (BAPV), which have been increasing the demand for green power [15]. This study defined a solar-energy building as a BAPV system in which the solar modules can be attached to and detached from the building without any structural damage. The BAPV that is referenced here is most commonly recognized as the solar panels placed on building roofs. Davis [16] proposed the Technology Acceptance Model (TAM) to forecast and explain public acceptance of new information technology. This model has since been adopted by many researchers, as it can be used in many industrial categories, and can be combined with various theories and research methods. Many empirical case studies have used this theory to extend their argument and research. However, few studies have applied this theory to the usage of renewable power in Taiwan. In this study, other than the traditional TAM dimensions of perceived usefulness (PU), perceived ease of use (PEOU), attitude toward using (AT), and purchasing behavior, three external variables are included, namely perceived safety (PS), electricity price trend, and green awareness, to explore consumers' intention of using the BAPV system. In order to halt the speed of global warming and satisfy the demand for electricity, there is an urgency to improve the installation rate of the photovoltaic power system. So far, the government has initiated the 'Million Rooftop PVs' program so as to provide subsidies and guidance to help residents install solar cells in their homes. With this program, the government hopes to raise the installation rate of the BAPV system equipment in the country. Since these residents are crucial for the successful of this program, this study decided to adopt the TAM model in order to investigate the acceptance and purchasing behavior of these residents. The main dimensions of the TAM model [16] were adapted from the Attitude model and the Theory of Reasoned Action (TRA) model [17]. The TAM model utilized the subjectively perceived usefulness (PU) and perceived ease of use (PEOU) to analyze consumer intention and predicted purchasing behavior. Other researchers further expanded this model or combined it with other theories to explore diverse issues. Due to the difference in references, data collection methods, and theoretical backgrounds, each research draws their own assumption and conclusions. The main theoretical framework of this study is the TAM model, with new external variables, namely consumers' perceived safety (PS) of the BAPV system, electricity price trend, attitude toward using (AT) the solar generation equipment, and consumers' green awareness. Lastly, this study will explore the consumers' intention to use the BAPV systems and their purchasing behavior. In summary, this study will investigate the following:

- Consumers' perceived usefulness (PU), perceived ease of use (PEOU), and perceived safety (PS) of the BAPV systems.

- Whether consumers' perceived usefulness (PU), perceived ease of use (PEOU), and perceived safety (PS) of the BAPV system will positively affect their attitude toward using (AT) and purchasing behavior.

- Whether external variables, such as electricity price trends and consumers' green awareness, will positively affect consumers' attitude toward using (AT) and purchasing behavior.

- Whether consumers' attitude toward using (AT) will directly affect their purchasing behavior.

\section{Hypothesis Developments and Research Model}

This study referenced the original structure of the TAM to explore consumers' perceptions regarding the BAPV. The study included three new external variables as latent variables to analyze the modified model. Thus, the model proposed by this study aims to find out: (1) the effects of the TAM model, with consumers' green awareness as the mediator and perceived safety (PS) as the moderator; (2) the effects on the new model, with the electricity price trend as the latent variable. 


\subsection{Grid-Connected Photovoltaic Power System}

A photovoltaic system, which is also called a PV system or solar power system, is used to supply usable solar power. The system consists of photovoltaic modules, one DC/AC inverter, a charge controller, and a lithium-ion battery. Standardized at six inches of polysilicon, each solar cell is able to generate $6.5 \mathrm{~A}$ to $8.5 \mathrm{~A}$ of galvanic current output. When the current has been generated continuously for an hour, the panel capacity will be between $0.72-0.94 \mathrm{kWh}$. After the power regulator converts the DC current into AC current and feeds it into the power grid, consumers can use the generated current together with the current provided by the utility companies. There are two types of photovoltaic power system: building-integrated photovoltaic systems (BIPV) and building-attached photovoltaic systems (BAPV). BIPV power systems consist of solar cells that are integrated into the building structures, such as glass facade buildings. Conversely, most of the BAPV power systems are regular solar cells that are installed on the rooftops of buildings. Furthermore, dismantling BAPV systems will not pose any risk to the building. Thus, in the mind of consumers, BAPV systems are cheaper and easier to install than BIPV systems, hence the motivation to use BAPV systems as the target of this study.

\subsection{Technology Acceptance Model (TAM)}

Davis [18] originally formulated the Technology Acceptance Model (TAM) in an attempt to understand if people are willing to accept a new technology system, and why. The model is based on the Theory of Reasoned Action (TRA) [17] and the Theory of Planned Behavior (TPB) [19].

TRA was first proposed by Fishbein and Ajzen, and was based on the theory of social psychology [18]. The model assumes that the individual performs an action or make a decision with their mind. Igbaria et al. [20] believed that people made the decision to take action rationally. Besides that, it is used to predict how individuals will present themselves based on their pre-existing attitudes and behavioral intentions. Therefore, the theory is widely used to investigate the relationship between intentions and actual behavior. According to this framework [18], as shown in Figure 1, both beliefs and evaluations affect Attitude toward behavior (AT) either positively or negatively. Normative beliefs and motivation to comply affect subjective norms (SNs) positively or negatively. The model predicts the actual behavior by behavior intention (BI), which consists of attitude toward behavior (AT) and subjective norm (SN). In addition, the behavior intention (BI) is used to measure the intentional strength of the individuals for particular actions. Attitude toward behavior (AT) means that the individuals perform an objective behavior with either positive or negative feeling. Subjective norm (SN) refers to the individuals' feelings toward the public perception. Dulany [21,22] found that subject of behavior is based on the cognitive effect of the interactive object regarding their knowledge, belief, consciousness, and so on. In the TRA model, the higher the SN, the higher the AT, and vice versa.

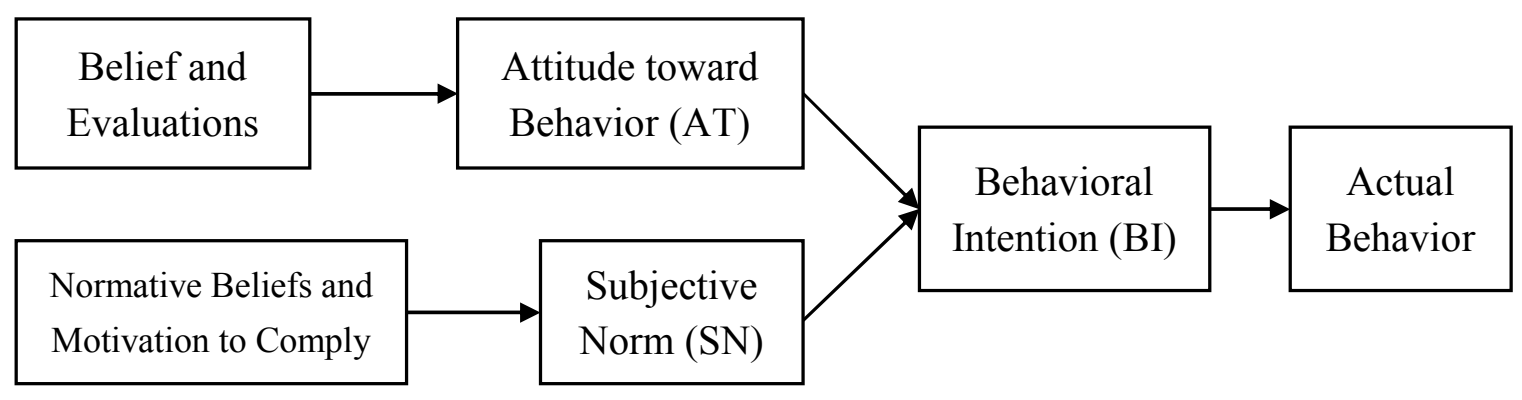

Figure 1. Theory of Reasoned Action (TRA).

TPB was proposed by Ajzen and based on the TRA [18,19,23,24]. The model, as shown in Figure 2, was based on the TRA with an added dimension. Attitude toward behavior (AT) and subjective norm (SN) are reused from the TRA model. Behavioral beliefs link the behavior of interest to expectations, and then positively affect the AT. Further, the social interaction generates normative beliefs, and turns to SN. In addition, Perceived Behavioral Control (PBC) was a new variable. The PBC model is defined 
as the degree of difficulty perceived by individuals as specific behavior [23]. It was a concept extending behavior from rational control to irrational control. The autonomous control perception that was taken from Social Cognitive Theory (SCT) will be affected by control beliefs, as they consist of cognitions of opportunities, resources, difficulties, or barriers $[25,26]$. Synthesizing the above point of views, we can conclude that the TPB model consists of behavioral action, the social environment, and self-efficacy. The TPB model showed that the individual's behavior intention (BI) is influenced by AT, SN, and PBC. In addition, both behavioral control and behavioral intention directly affect the individual's actual behavior. From the theoretical evolution of the TRA model to the TPB model, we can see the extension of simply investigating a specific behavior to exploring social interpersonal interaction, before including the complex relationship between behavior intention and actual behavior.

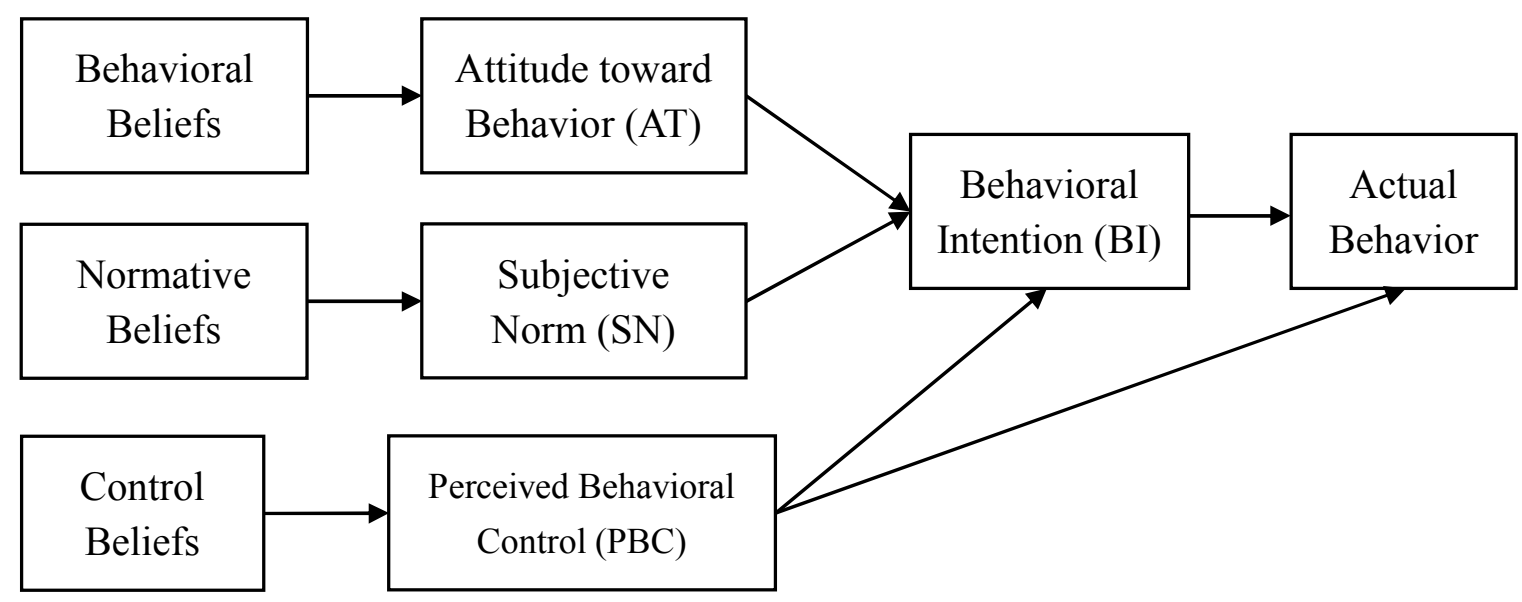

Figure 2. Theory of Planned Behavior (TPB).

The purpose of the TAM model is to predict and explain user acceptance of new information or technology systems [16]. Due to its simple conceptual model, it was first used in information systems (IS). We can utilize the TAM model to find out whether the public will accept a particular new technology or not [27]. After that, many studies have developed extended models based on the TAM model, such as the Unified Theory of Acceptance Use of Technology (UTAUT) [28]. The TAM model replaces and merges the attitude measures and behavioral elements of the TRA model and the TPB model. The core dimensions of the TAM model are perceived ease of use (PEOU) and perceived usefulness (PU). Davis [16] defined PEOU as the degree to which a person believes that using a particular system would be free from effort, and the PU as the degree to which a person believes that using a particular system would enhance his or her job performance. This study postulates that the perceived ease of use (PEOU) positively affects the PU, and both variables will positively affect the AT. Besides, this study also posits that the external variables will affect the PEOU and PU. Moreover, as shown in Figure 3, the AT will directly affect the BI, and the BI will affect the use of the actual system.

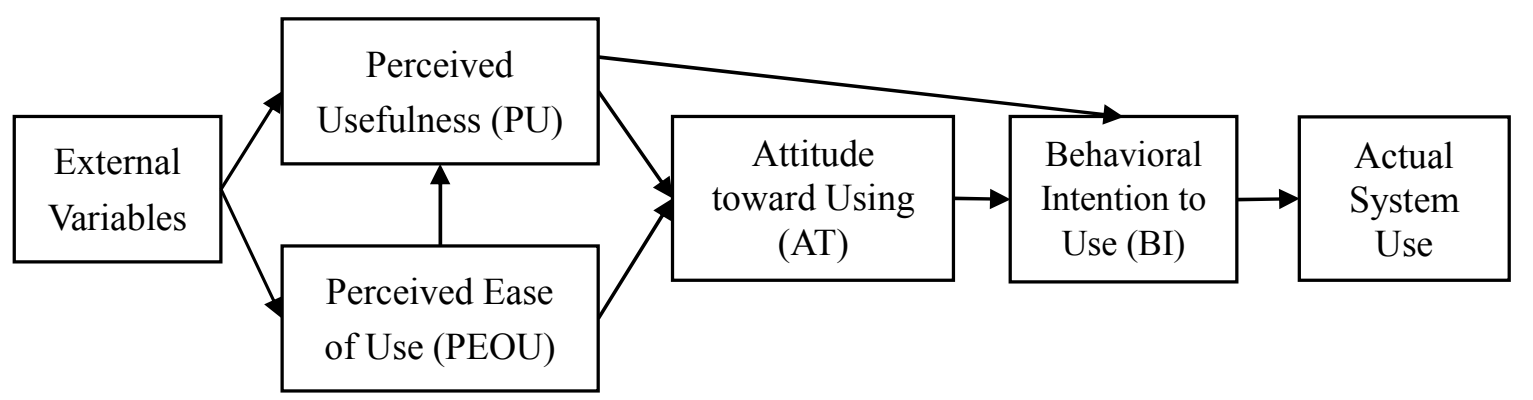

Figure 3. Technology Acceptance Model (TAM). 
Davis (1989) adopted multiple regression models to expend on more complex analytical methods. In the research background, the model was first used for Learning Management Systems [29] or an educational e-Learning Management system [30]. In recent years, the model has been used to explore people behaviors, new invention technology, and time-change thought. Chuah et al. [31] extended the TAM model to wearable technologies, and identified usefulness as one of the drivers to smartwatch adoption. In addition, Kardooni et al. [32] investigated the factors that influence renewable energy technology acceptance in peninsular Malaysia, and attempted to show the impact of cost and knowledge on the TAM model. Yet, some of the studies' hypotheses were not proven, while some of the dimensions or variables were improved in order to better suit the research subjects [33]. Results have shown that PEOU does not significantly affect BI and the actual system use at $50 \%$ and $36 \%$, respectively. Thus, as shown in Figure 4, by eliminating high ratios of non-significant dimensions, we propose the following hypothesis:

Hypothesis 1 (H1). Perceived ease of use (PEOU) positively affects perceived usefulness (PU).

Hypothesis 2 (H2). Perceived usefulness (PU) positively affects attitude toward using (AT).

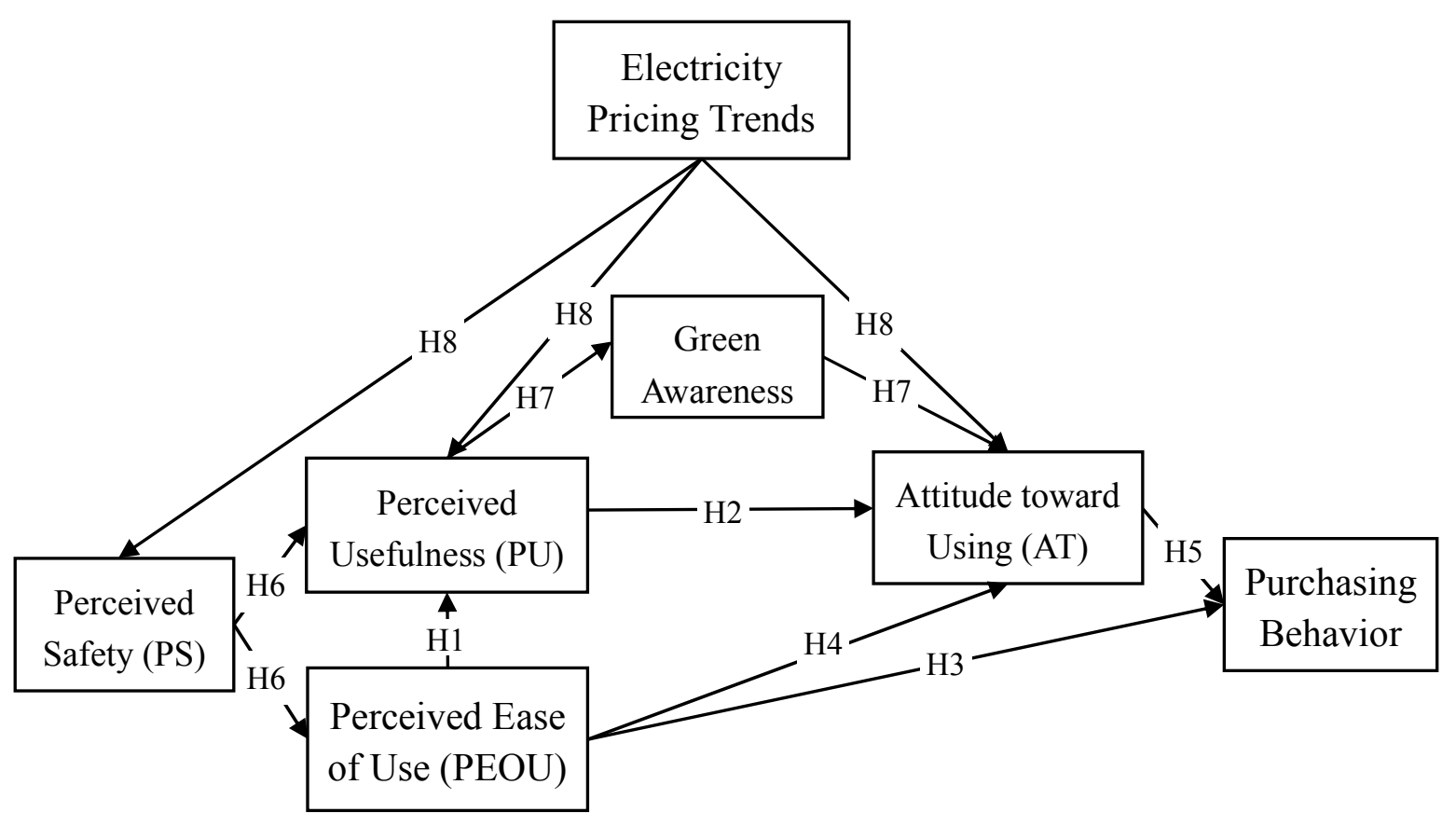

Figure 4. Hypotheses on the Proposed Model.

The BI means the individual's anticipated or planned behavior in the future [34]. It represents an individual's expectations about a particular behavior in a given setting, and can predict the likelihood of action [19]. Moreover, actual system use is defined as a form of external psychomotor response that is quantified by individual users' real actions [16]. Purchasing behavior is the decision processes and acts of people related to buying products [35-37]. According to the above definitions, this study defined the purchasing behavior as behavioral intention (BI) and actual system use. Therefore, intention is determined by the person's positive or negative attitudes toward the decision, it is expected that:

Hypothesis 3 (H3). Perceived ease of use (PEOU) positively affects purchasing behavior.

Hypothesis 4 (H4). Perceived ease of use (PEOU) positively affects attitude toward using (AT). 
Hypothesis 5 (H5). Attitude toward using (AT) positively affects purchasing behavior.

Legris et al. [20] explored several cases of TAM models, and found an important conclusion: the most important variable of the external variables is system quality [38-40]. The system quality is the preposition variable for the PU, and the PEOU and will positively affect these two variables [41]. Thus, it is conceivable that system quality will affects consumers' evaluation of the usefulness and ease of use of the BAPV equipment. In addition, numerous articles have pointed out that the system quality is an important indicator for power equipment [42,43]. The operational definitions of the system qualities are system integration, system flexibility, and system security [44,45]. Thus, the study chooses one dimension of system qualities, system security, as it is most relevant with the consumer. We named it perceived safety (PS). Therefore, we propose the following:

Hypothesis 6 (H6). Perceived safety (PS) moderates the relationship between perceived usefulness (PU) and perceived ease of use (PEOU).

\subsection{Green Awareness}

The Intergovernmental Panel on Climate Change shows that the global average temperature has increased by more than $1.5^{\circ} \mathrm{C}$ per year [46]. The leading contributor to global warming is greenhouse gas. The primary greenhouse gases in the Earth's atmosphere are water vapor, carbon dioxide, methane, nitrous oxide, and ozone. Without these greenhouse gases, the Earth would be too cold to sustain any life. However, too many greenhouse gases will cause the temperature to rise, melting polar ice caps, causing the extinction of species, and other catastrophes. The Environmental Protection Agency reported that energy production and use (including fuels used by vehicles) represent the largest source of greenhouse gas emissions around the world, followed by agriculture [47]. This means that people should reduce their use of power resources, and then maybe we can halt the rate of global warming. Several research studies have indicated that the threat from global warming has increased and requires more attention [48]. Roughly 6.4 million refugees around the world have been displaced because of global warming [2]. Lehne et al. [4] pointed out that the number of people displaced by climate conflict has now risen above 65 million, and the study estimated that the vast majority lack of clean water, safe places, and secure energy services. Besides that, higher temperatures will cause the Arctic ice to melt. The large-scale melting of these Arctic ices will lead to rising sea levels and cause islands or coastal countries, such as Hong Kong and Singapore, to disappear. Recognizing the terrible catastrophe in the future, countries are trying to strike a balance between economic development and sustainable development. Governments from many developed countries are starting to take green consciousness seriously; for example, the Copenhagen Agreement is a climate change accord that delegates at the Conference of Parties to the United Nations Framework Convention on Climate Change [49] agreed upon. Green awareness is the consumer awareness of green products. The adoption of renewable energy is a socially-oriented process in which individuals' perceptions play a key role [50]. Green awareness has been widely promoted in various countries. Many researchers have looked into this issue, and a number of them have examined consumer preferences for related products or services [51,52]. Moreover, many studies have explored the relationship between green awareness, green energy consumption, and purchasing behavior [53]. Green purchase intention refers to an individual's inclination to buy and use products [54]. Consumer green marketing awareness is achieved when customers gain confidence in the BAPV equipment, which would then influence their green product purchase behavior $[55,56]$. That is, people who perceive the system as useful and also have green awareness will change their purchasing behavior, meaning that people with a higher green awareness will show a higher attitude toward using. In addition, there is a growing awareness of environmental protection in the consumer market nowadays, so green awareness may affect the attitude of consumers' purchasing behavior [57-59]. Therefore, we propose: 
Hypothesis 7 (H7). Green awareness mediates the relationship between perceived usefulness (PU) and attitude toward using (AT).

\subsection{Electricity Price Trend}

This study defined electricity pricing as the sales price of electricity to the end user provided by the electricity business as well as the Taiwan Power Company. As electricity prices fluctuate, this study will explore the impact of short-term (half-year) and long-term (three-year) price increases on consumer attitudes toward using the BAPV systems. Price perception is the process by which consumers convert prices into meaningful cognition [60-62]. The price perception of a consumer does have an impact on their psychology, and it will be reflected in consumer behavior [36]. Prices need to fall within the acceptable range in the mind of the consumer, as only then will the transaction be made. Thus, electricity pricing certainly affects the attitude toward using and purchasing behavior. Dodds and Monroe [63] pointed out the perceived value is the alternative between perceived benefit and perceived costs $[64,65]$. It means that consumers will measure the difference between the benefits that they will receive and the costs that they have to pay when they purchase the goods or service [66,67]. The perceived value is equal to the difference between the two [68]. This study takes electricity to have a positive influence on the perceived value, and on the other hand, takes the electricity price to have a negative influence on the perceived value. Thus, this study wants to figure out whether consumers of the green power generation equipment or the BAPV systems will have higher purchasing intentions and thus improve the perceived usefulness when the negative influence increases [69]. Therefore, we propose:

Hypothesis 8 (H8). The electricity price trend positively affects perceived safety (PS), perceived usefulness $(P U)$, and attitude toward using (AT).

\section{Methodology}

\subsection{Sample and Data Collection}

The sample for this study is adults older than 20 years old. The BAPV under investigation is very difficult to understand because of its new developing equipment in Taiwan. In addition, the highly educated respondents can easily understand and respond to the questionnaires under consideration than those who are less educated. Therefore, most of the respondents are college graduates. Next, the collected responses are from personal interviews and internet surveys. The two-way collection method enables widely and averagely select a sample of every region, and can explore consumers' thought in more detail. The collection period was from October 2015 to February 2016. Samples were collected from residents of northern Taiwan by the convenience sampling model. In convenience samples, responses that are more readily accessible to the researcher are more likely to be included. In total, 483 samples were collected, including 336 paper samples and 147 internet survey samples. The internet survey samples are collected from community websites, including Facebook, Line, and Instagram.

\subsection{Measure Scale}

This study adopted multiple questions to analyze each dimension of the model with a seven-point Likert scale to denote the preference of items. A scale score of one denotes 'Strongly Disagree', and seven denotes 'Strongly Agree'. As shown in Table 1, the items used consist of the PU and the PEOU as adopted from Davis [23], the PS from DeLone and McLean [44], the AT and purchasing behavior from Taylor and Todd [70], green awareness adopted to New Environmental Paradigm (NEP) as developed by Dunlap et al. [71], and electricity price trend from Petrick [72]. We combined and adapted their scales to fit the context of this study. 
Table 1. Operational definition and measurements.

\begin{tabular}{|c|c|c|}
\hline Variable & Operational Definition & Measurement \\
\hline Perceived usefulness & $\begin{array}{l}\text { The degree to which the user-satisfaction of the individual } \\
\text { was achieved }\end{array}$ & Davis [13] \\
\hline Perceived ease of use & The degree to which the equipment was easy to use & Davis [13] \\
\hline Perceived safety & The degree to which the equipment was used safely & DeLone \& McLean [44] \\
\hline Electricity price trend & $\begin{array}{l}\text { The degree to which the electricity pricing fluctuated } \\
\text { up/down }\end{array}$ & Petrick [72] \\
\hline Attitude toward using & $\begin{array}{l}\text { A feeling or opinion about solar power systems that led to } \\
\text { an action }\end{array}$ & Taylor \& Todd [70] \\
\hline Purchasing behavior & $\begin{array}{l}\text { The intention to which the user was willing to } \\
\text { buy/recommend solar power systems or not }\end{array}$ & Taylor \& Todd [70] \\
\hline Green awareness & $\begin{array}{l}\text { The public awareness of environmental awareness and } \\
\text { maintained behavior toward the natural environment }\end{array}$ & Dunlap et al. [71] \\
\hline
\end{tabular}

\subsection{Statistical Data Analysis}

The sample size required for this study was computed based on the recommendation of Hair et al. [73] for a desired level of 15-20 observations per studied variable. Our study has seven constructs (two items for PU, two items for PE, three items for PS, two items for EP, three items for $\mathrm{AT}$, three items for $\mathrm{PB}$, and three items for GR, totaling 18 items), resulting in an ideal sample size of $360(=18 \times 20)$ respondents. In this study, the surveyed area consists of cities in the north area of Taiwan with a total sample data set of 510 responses. After eliminating 27 incomplete questionnaires, a total of 483 usable sample sets were collected, with an effective response rate of approximately $94.7 \%$. Table 2 shows the socio-demographic profile of the samples. According to the Directorate-General of Budget, which is attached to the Accounting and Statistics branch of the government, the individual disposable income rate in Taiwan is approximate $78.8 \%$ [74]. The average monthly salaries of the individual with a college degree and one-year work experience is between NT\$20,001-60,000. Therefore, a person may have a disposable income of around NT $\$ 15,760$ to NT $\$ 47,280$ per month. Thus, the average disposable income per month is NT\$31,520. Assuming a household of four, they will be able to save a NT $\$ 240,000$ prepay deposit for 24 square foot roof-type solar panels in two years [35]. In conclusion, $92 \%$ of respondents had a degree above college. Approximately $41.6 \%$ of the participants indicated that they had a monthly income of NT $\$ 20,001$ to NT\$60,000, and $23.6 \%$ of the participants responded that they earned a monthly income of more than NT\$60,001. Structural equation modeling was utilized to test the hypotheses, which consists of a measurement model and a structural model. The purpose of the measurement model is to figure out the relationship between the observed variables and the potential variables. Besides, the structural model uses path analysis to explore the potential variables' relationship and examine the significance of the coefficient [75].

Table 2. Socio-demographic profile.

\begin{tabular}{|c|c|c|c|c|c|}
\hline Variables & Frequency & Percent (\%) & Variables & Frequency & Percent (\%) \\
\hline \multicolumn{6}{|l|}{ Gender $(n=483)$} \\
\hline Male & 222 & 46.0 & Master graduate & 161 & 33.3 \\
\hline Female & 261 & 54.0 & PhD graduate & 10 & 2.1 \\
\hline Age & & & Monthly personal income & & \\
\hline $20-29$ & 195 & 40.4 & Less than NT $\$ 20,000$ & 168 & 34.8 \\
\hline $30-39$ & 73 & 15.1 & NT $\$ 20,001-\$ 40,000$ & 83 & 17.2 \\
\hline $40-49$ & 84 & 17.4 & NT $\$ 40,001-\$ 60,000$ & 118 & 24.4 \\
\hline $50-59$ & 91 & 18.8 & NT $\$ 60,001-\$ 80,000$ & 52 & 10.8 \\
\hline 60 years and older & 40 & 8.3 & NT $\$ 80,001-\$ 100,000$ & 28 & 5.8 \\
\hline District & & & NT\$100,001-\$150,000 & 28 & 5.8 \\
\hline Taipei City & 183 & 37.9 & Over NT $\$ 150,001$ & 6 & 1.2 \\
\hline
\end{tabular}


Table 2. Cont.

\begin{tabular}{cccccc}
\hline Variables & Frequency & Percent (\%) & Variables & Frequency & Percent (\%) \\
\hline New Taipei City & 171 & 35.4 & Career & & 0.2 \\
Other Northern Area & 129 & 26.7 & Traditional occupation & 1 & 3.7 \\
Marital status & & & Manufacturing industry & 18 & 13.7 \\
Single or not married & 267 & 55.3 & Information technology & 66 & 10.8 \\
Married & 215 & 44.5 & Service industry & 52 & 6.2 \\
Education & & & Financial industry & 30 & 67 \\
Freelance & 24 & 5.0 & Civil servants & 157 & 32.5 \\
Others & 19 & 3.9 & Student & 21 & 4.3 \\
Junior high school & 1 & 0.2 & Housekeeper & 28 & 5.8 \\
High school graduate & 37 & 7.7 & Retired & & \\
College graduate & 274 & 56.7 & &
\end{tabular}

\section{Results}

\subsection{Descriptive Statistics and Covariance Matrix}

The study originally received a total of 612 questionnaires from all of the cities of Taiwan. However, as the southern cities in Taiwan adopted large-scale built solar panels (ground-type solar panels) instead of the BAPV systems, questionnaires from the southern cities were omitted. The demographic profile of consumers' experience and understanding collected from the questionnaires is shown in Table 3. More than $87.4 \%$ of the respondents never used solar power generation equipment before. More than $50 \%$ of the participants had used the equipment for less than three years, and over $60 \%$ in this group used it for less than a year. Based on questions \#3 and \#4 in the survey, over $40.6 \%$ of respondents were not familiar with the related regulations, and almost $57 \%$ of respondents had never received or had any information from the government or Taiwan Power Company on this topic.

Table 3. Using experience and understanding.

\begin{tabular}{ccc}
\hline Variables & Frequency & Percent (\%) \\
\hline Using experience $(n=483)$ & & \\
Yes & 61 & 12.6 \\
No & 422 & 87.4 \\
Using period & & \\
Never & 422 & - \\
<1 year & 24 & 39.3 \\
1-3 years & 18 & 29.5 \\
3-5 years & 4 & 6.6 \\
Over 5 years & 15 & 24.6 \\
Completely understand & & \\
Partially understand & 12 & 2.5 \\
None & 196 & 40.6 \\
Awareness degree of recovery-pricing regulation & 275 & 56.9 \\
Awareness degree of the government subsidy regulation & & \\
Completely understand & 12 & 2.5 \\
Partial understand & 196 & 40.6 \\
None & 275 & 56.9 \\
\hline
\end{tabular}

In addition to that, the covariance scores among variables were calculated in Table 4 . It showed the raw covariance scores for structural equation modeling (SEM) analysis. The covariance scores were significant $(p<0.01)$. The covariance matrix shows the relationship among the sets of random variables. 
Table 4. Covariance matrix and descriptive statistics.

\begin{tabular}{|c|c|c|c|c|c|c|c|c|c|c|c|c|c|c|c|c|c|c|c|c|}
\hline Items & PU1 & PU2 & PE1 & PE2 & PS1 & PS2 & PS3 & EP1 & EP2 & AT1 & AT2 & AT3 & PB1 & PB2 & PB3 & GR1 & GR2 & GR3 & Mean & Std. Dev \\
\hline PU1 & 1.15 & & & & & & & & & & & & & & & & & & 5.92 & 1.07 \\
\hline PU2 & 0.62 & 1.78 & & & & & & & & & & & & & & & & & 5.36 & 1.34 \\
\hline PE1 & 0.50 & 0.84 & 2.61 & & & & & & & & & & & & & & & & 3.96 & 1.62 \\
\hline PE2 & 0.36 & 0.61 & 1.52 & 2.86 & & & & & & & & & & & & & & & 4.17 & 1.69 \\
\hline PS1 & 0.50 & 0.85 & 0.88 & 0.64 & 2.05 & & & & & & & & & & & & & & 4.77 & 1.43 \\
\hline PS2 & 0.51 & 0.86 & 0.89 & 0.65 & 1.48 & 1.74 & & & & & & & & & & & & & 4.97 & 1.32 \\
\hline PS3 & 0.38 & 0.65 & 0.67 & 0.49 & 1.12 & 1.13 & 1.75 & & & & & & & & & & & & 5.33 & 1.32 \\
\hline EP1 & 0.33 & 0.55 & 0.32 & 0.23 & 0.54 & 0.54 & 0.41 & 1.88 & & & & & & & & & & & 5.11 & 1.37 \\
\hline EP2 & 0.33 & 0.55 & 0.32 & 0.24 & 0.54 & 0.55 & 0.41 & 1.57 & 1.80 & & & & & & & & & & 5.25 & 1.34 \\
\hline AT1 & 0.43 & 0.73 & 0.42 & 0.31 & 0.59 & 0.60 & 0.45 & 0.59 & 0.59 & 1.26 & & & & & & & & & 5.75 & 1.13 \\
\hline AT2 & 0.45 & 0.75 & 0.44 & 0.32 & 0.61 & 0.62 & 0.47 & 0.61 & 0.61 & 1.04 & 1.53 & & & & & & & & 5.40 & 1.24 \\
\hline AT3 & 0.33 & 0.55 & 0.32 & 0.23 & 0.45 & 0.45 & 0.34 & 0.45 & 0.45 & 0.76 & 0.79 & 1.03 & & & & & & & 6.00 & 1.02 \\
\hline PB1 & 0.41 & 0.78 & 0.53 & 0.38 & 0.58 & 0.59 & 0.44 & 0.58 & 0.58 & 0.89 & 0.93 & 0.68 & 1.49 & & & & & & 5.60 & 1.23 \\
\hline PB2 & 0.46 & 0.77 & 0.59 & 0.43 & 0.65 & 0.66 & 0.50 & 0.65 & 0.65 & 1.00 & 1.04 & 0.75 & 1.11 & 1.53 & & & & & 5.48 & 1.24 \\
\hline PB3 & 0.47 & 0.69 & 0.60 & 0.43 & 0.66 & 0.67 & 0.50 & 0.66 & 0.66 & 1.01 & 1.05 & 0.76 & 1.12 & 1.26 & 1.67 & & & & 5.23 & 1.30 \\
\hline GR1 & 0.10 & 0.17 & 0.14 & 0.10 & 0.14 & 0.15 & 0.11 & 0.09 & 0.09 & 0.24 & 0.24 & 0.18 & 0.21 & 0.24 & 0.24 & 0.70 & & & 6.38 & 0.83 \\
\hline GR2 & 0.07 & 0.12 & 0.10 & 0.08 & 0.11 & 0.11 & 0.08 & 0.07 & 0.07 & 0.17 & 0.18 & 0.13 & 0.16 & 0.17 & 0.18 & 0.31 & 0.50 & & 6.59 & 0.71 \\
\hline GR3 & 0.09 & 0.15 & 0.13 & 0.09 & 0.13 & 0.13 & 0.10 & 0.08 & 0.08 & 0.21 & 0.22 & 0.16 & 0.19 & 0.21 & 0.21 & 0.38 & 0.28 & 0.50 & 6.55 & 0.70 \\
\hline
\end{tabular}




\subsection{Confirmatory Factor Analysis (CFA)}

Confirmatory factor analysis (CFA) is employed to test the reliability and validity, and the results are shown in Table 5. Cronbach's alpha is used to analyze the internal consistency of the construct and the reliability of the items. The highest reliability test is the factor of the electricity price trend (0.92), and in descending order, the reliability report shows the factors of purchasing behavior (0.90), attitude toward using (0.87), perceived safety (0.86), green awareness (0.80), perceived ease of use (0.71), and perceived usefulness (0.63), wherein the acceptable Cronbach's alpha coefficient reliability is between $0.60-0.70$ (Peterson [76]). The results of CFA were indicated as at an excellent level $\left(\chi^{2}=288.432, \mathrm{df}=121, \chi^{2} / \mathrm{df}=2.384, p\right.$-value $=0.000, \mathrm{GFI}=0.938, \mathrm{AGFI}=0.912, \mathrm{NFI}=0.945$, $\mathrm{CFI}=0.967$, RMSEA $=0.054)$.

Table 5. Results of confirmatory factor analysis (CFA). AVE: average variance extracted, CCR: composite construct reliability, SMC: squared multiple correlation.

\begin{tabular}{|c|c|c|c|c|c|}
\hline Scale Items & Standardized Loadings & $p$-Values & SMCs & CCR & AVE \\
\hline Perceived usefulness $(\alpha=0.63)$ & & & & 0.62 & 0.45 \\
\hline PU1 & 0.57 & - & 0.33 & & \\
\hline PU2 & 0.76 & $* * *$ & 0.58 & & \\
\hline Perceived ease of use $(\alpha=0.71)$ & & & & 0.74 & 0.59 \\
\hline PE1 & 0.89 & - & 0.79 & & \\
\hline PE2 & 0.62 & $* * *$ & 0.38 & & \\
\hline Perceived safety $(\alpha=0.86)$ & & & & 0.87 & 0.69 \\
\hline PS1 & 0.84 & $* * *$ & 0.71 & & \\
\hline PS2 & 0.93 & $* * *$ & 0.87 & & \\
\hline PS3 & 0.70 & - & 0.49 & & \\
\hline \multicolumn{6}{|l|}{ Electricity price trend $(\alpha=0.92)$} \\
\hline EP1 & 0.83 & $* * *$ & 0.69 & 0.85 & 0.73 \\
\hline EP2 & 0.88 & - & 0.77 & & \\
\hline Attitude toward using $(\alpha=0.87)$ & & & & 0.87 & 0.69 \\
\hline AT1 & 0.89 & - & 0.80 & & \\
\hline AT2 & 0.84 & $* * *$ & 0.71 & & \\
\hline AT3 & 0.75 & $* * *$ & 0.56 & & \\
\hline Purchasing behavior $(\alpha=0.90)$ & & & & 0.90 & 0.75 \\
\hline PB1 & 0.82 & - & 0.67 & & \\
\hline PB2 & 0.90 & $* * *$ & 0.81 & & \\
\hline PB3 & 0.87 & $* * *$ & 0.76 & & \\
\hline Green awareness $(\alpha=0.80)$ & & & & 0.81 & 0.58 \\
\hline GR1 & 0.78 & $* * *$ & 0.39 & & \\
\hline GR2 & 0.68 & $* * *$ & 0.54 & & \\
\hline GR3 & 0.82 & - & 0.33 & & \\
\hline
\end{tabular}

Model fit statistics: $\mathrm{CMIN}\left(\chi^{2}\right)=288.432, \mathrm{df}=121, \mathrm{CMIN} / \mathrm{df}=2.384, p$-value $=0.000, \mathrm{GFI}=0.938, \mathrm{AGFI}=0.912$, $\mathrm{NFI}=0.945, \mathrm{CFI}=0.967, \mathrm{RMSEA}=0.054 .{ }^{* * *}$ significant at $p<0.001$.

For evidence of convergent validity [77], the standardized loadings and squared multiple correlation (SMC) are examined. SMC reflects the extent to which individual measurement variables are affected by potential variables. The SMC value that was obtained was greater than 0.5 , which exceed the recommended convergent validity and was also accepted at 0.4 [70]. If the SMC is less than 0.4, any value above 0.2 is still valid [78,79]. The result of composite construct reliability (CCR) is the ratio of true variance to total variances; therefore, the higher the values of CCR, the higher internal consistency. Fornell and Larcker [80] suggested that the CCR value of potential variables is preferred to be over 0.60 . (CCR; 0.62 for perceived usefulness, 0.74 for perceived ease of use, 0.87 for perceived safety, 0.85 for electricity price trend, 0.87 for attitude toward using, 0.90 for purchasing behavior, and 0.81 for green awareness).

Average variance extracted (AVE) includes an explanatory ability of potential variables to observe variables; in short, it is the average of the SMC. Key measurement research studies have suggested 
that the AVE should be greater than $0.5[80,81]$; however, it is not easy to reach in practical research. Therefore, for a study with seven AVE values, it is acceptable to have five to six items meeting the standard value [73]. In this study, the following AVE values were obtained: 0.45 for perceived usefulness, 0.59 for perceived ease of use, 0.69 for perceived safety, 0.73 for electricity price trend, 0.69 for attitude toward using, 0.75 for purchasing behavior, and 0.58 for green awareness.

\subsection{Structural Equation Model Analysis and Hypothesis Test Results}

The model fit for structural equation is good with $\chi^{2}=288.432, \mathrm{df}=121, \chi^{2} / \mathrm{df}=2.384, p$-value $=0$, $\mathrm{GFI}=0.938, \mathrm{AGFI}=0.912, \mathrm{NFI}=0.945, \mathrm{CFI}=0.967, \mathrm{RMSR}=0.067$, and RMSEA $=0.054$, indicating a strong predictive validity. The standardized path coefficients with associated $p$-values for relationships in the model are shown in Table 6. The purpose of this study is to examine the below effects: perceived ease of use on perceived usefulness (H1), perceived usefulness on attitude toward using (H2), perceived ease of use on purchasing behavior (H3) and attitude toward using (H4), attitude toward using on purchasing behavior (H5), perceived safety on perceived ease of use and perceived usefulness (H6), perceived usefulness on green awareness and green awareness on attitude toward using (H7), and electricity price trend on perceived safety, perceived usefulness, and attitude toward using (H8). Among these hypotheses, H4 was supported significantly with $p<0.05 *$, and H3 was supported significantly with $p<0.01^{* *}$. The rest of the hypotheses were also supported significantly with $p<0.001^{* * *}$. The results of hypotheses are depicted in Table 5, which also included standardized loadings, $p$-values, SMCs, CCR, and AVE. H1 was supported $(\beta=0.13)$, meaning that perceived ease of use positively affects perceived usefulness. Perceived usefulness was shown to positively affect attitude toward using, as $\mathrm{H} 2$ was supported $(\beta=1.11)$. H3 was supported $(\beta=0.08)$, meaning that perceived ease of use positively affects purchasing behavior. H5 was proved ( $\beta=0.83$ ), showing that attitude toward using does positively affect purchasing behavior. H6 was supported $(\beta=0.3$, $\beta=0.79$ ), meaning that perceived safety is the moderator between perceived usefulness and perceived ease of use. Both paths of $\mathrm{H} 7$ were supported $(\beta=0.26, \beta=0.34)$, meaning that perceived usefulness is the antecedent of green awareness. Two out of three paths for $\mathrm{H} 8$ were also supported $(\beta=0.26$, $\beta=0.15)$, meaning that the electricity price trend positively affects both perceived safety and attitude toward using. One path of $\mathrm{H} 8$ was supported $(\beta=-0.11)$, showing that the electricity price trend negatively affects perceived usefulness. Lastly, $\mathrm{H} 4$ was also supported $(\beta=-0.11)$, meaning that perceived ease of use negatively affects attitude toward using. Figure 5 describes the constructs of all of the structural paths.

Table 6. The Results of the hypotheses.

\begin{tabular}{ccccc}
\hline & Hypothesized Paths & Coefficient & $p$-Values & Remarks \\
\hline H1 & Perceived ease of use $\rightarrow$ perceived usefulness & 0.13 & $* * *$ & Supported \\
H2 & Perceived usefulness $\rightarrow$ attitude toward using & 1.11 & $* * *$ & Supported \\
H3 & Perceived ease of use $\rightarrow$ purchasing behavior & 0.08 & $0.002 * *$ & Supported \\
H4 & Perceived ease of use $\rightarrow$ attitude toward using & -0.11 & $0.035 *$ & Supported \\
H5 & Attitude toward using $\rightarrow$ purchasing behavior & 0.83 & $* * *$ & Supported \\
H6 & Perceived safety $\rightarrow$ perceived usefulness & 0.30 & $* * *$ & Supported \\
& Perceived safety $\rightarrow$ perceived ease of use & 0.79 & $* * *$ & Supported \\
H7 & Perceived usefulness $\rightarrow$ green awareness & 0.26 & $* * *$ & Supported \\
& Green awareness $\rightarrow$ attitude toward using & 0.34 & $* * *$ & Supported \\
H8 & Electricity price trend $\rightarrow$ perceived safety & 0.26 & $* * *$ & Supported \\
& Electricity price trend $\rightarrow$ perceived usefulness & -0.11 & $* * *$ & Supported \\
& Electricity price trend $\rightarrow$ attitude toward using & 0.15 & $* * *$ & Supported \\
\hline
\end{tabular}

* Significant at $p<0.05,{ }^{* *}$ Significant at $p<0.01,{ }^{* * *}$ Significant at $p<0.001$. 


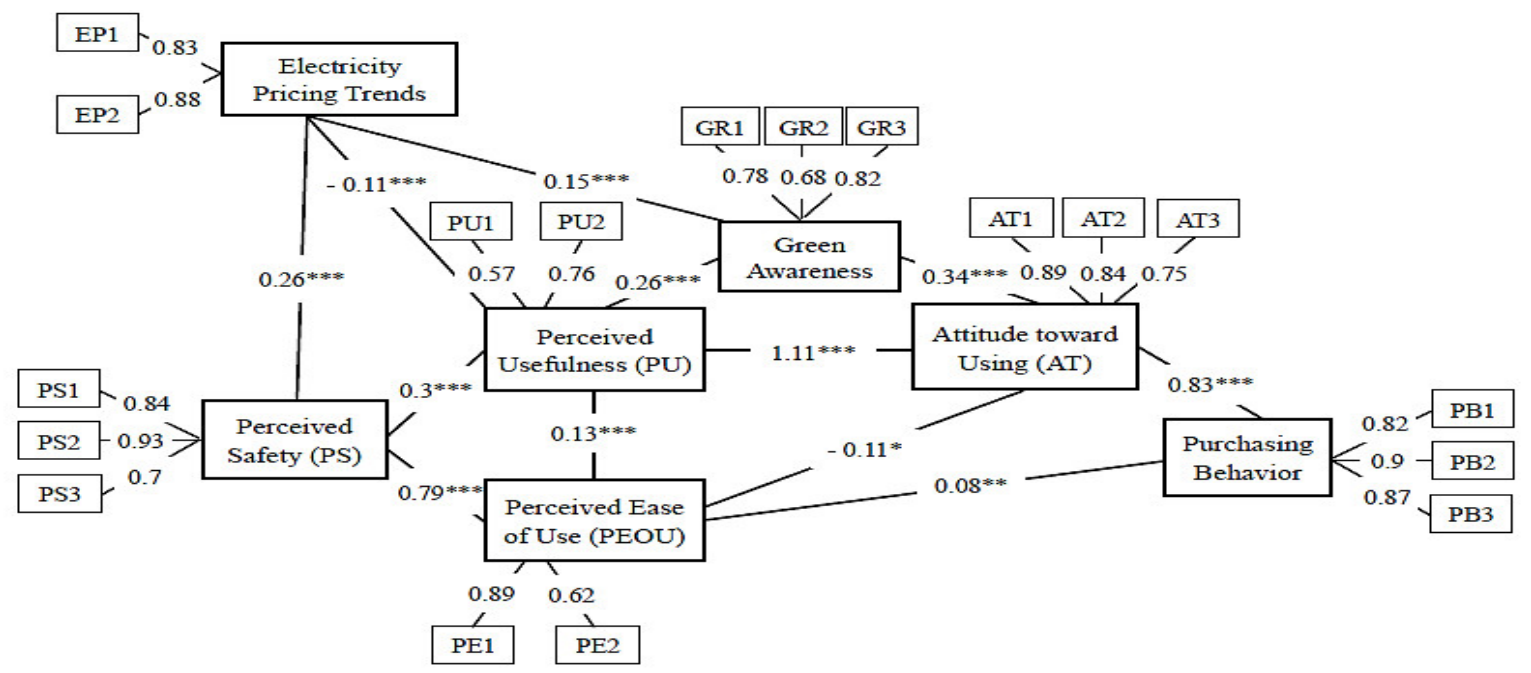

Figure 5. Structure equation modeling. ${ }^{*}$ Significant at $p<0.05,{ }^{* *}$ Significant at $p<0.01,{ }^{* * *}$ Significant at $p<0.001$.

\section{Conclusions and Policy Implications}

The government in Taiwan has agreed to decommission all of the nuclear power plants and become totally nuclear-free by the year 2025. Without these nuclear power plants, existing power generation will not be able to meet the demand for electricity. In order to halt the speed of global warming and satisfy the demand for electricity, there is an urgency to improve the installation rate of photovoltaic power systems. So far, the government has initiated the 'Million Rooftop PVs' program so as to provide subsidies and guidance to help residents install solar cells in their homes. In this study, we adopt the TAM model to investigate the acceptance and purchasing behavior of the consumers' intention to use the BAPV systems. Three external variables are included-namely perceived safety (PS), electricity price trend, and green awareness-to explore consumers' intentions of using the BAPV system. The most significant contribution of this study is applying a theoretical model with various variables to understand the unknown cognition and using attitude toward solar power systems. Unlike previous studies, we modified the original main structure of the TAM model and added new observed variables such as perceived safety, green awareness, and electricity price trend to explore the relationships among these dimensions. Besides, the observed variables can be divided into two parts. The first part refers to the intrinsic perception in consumers' minds such as green awareness, and the other part refers to the inner cognition driven by external influences such as electricity price trend and perceived safety. These explorations not only provide future research studies with knowledge about consumer attitude with respect to building-attached photovoltaic equipment, they also give managerial suggestions to the government or related enterprises. The hypotheses are supportable in terms of overall model fit, paths' significance, and literature explanation. The objective of this study was to provide an integrated approach to better understand purchasing behavior and the relationships between perceived usefulness, perceived ease of use, perceived safety, attitude toward using, green awareness, and electricity price trend in the BAPV system. According to the model fit results, the study found purchasing behavior to directly affected by perceived ease of use, and indirectly affected by perceived usefulness and attitude toward using. Overall, the results of this study are fairly consistent with the proposed hypotheses. We found that when PEOU is the antecedent of PU and AT, the model fit shows a positive influence. However, when PEOU directly affects AT, it shows a negative influence. These two opposing results show that consumers lack an awareness of PEOU. Thus, in order to get a positive AT, PEOU and PU had to be synergized. Further, the PEOU also has a negative influence on the antecedent of AT, but it affects purchasing behavior positively.

In addition to the above results, the electricity price trend has a significant effect on the PU. The operational definition of the electricity price trend is the degree to which the electricity pricing 
goes up or down. The solar electricity pricing is a substitute for normal electricity pricing [82-85]. It is easy to understand the rise in consumer attitude toward using solar power equipment when the normal electricity prices fall. Conversely, the electricity price trend has a significantly negative effect on the PU. As shown in Table 3, the public is not aware of the possibility of reselling the green electricity that they generated back to the Taiwan Power Company at a higher rate. Moreover, understanding of the recovery price among consumers is also weak. These have led the consumers to have a negative perceived usefulness regarding the electricity price trend, which in turn was reflected as an unexpected relationship between these two dimensions. We also found that the electricity price trend positively affects both the PS and green awareness. The first pairing means that a higher electricity price trend will lead to a higher PS. As the prices of electricity increase, the public will realize that decommissioning nuclear power plants will lead to a severe electricity shortage. Coupled with the safety fears of nuclear power plants and the 'not-in-my-back-yard' (NIMBY) effect, the public will perceive solar power generation equipment, such as BAPV systems, to be safer than nuclear power generation, thus raising their PS of the BAPV equipment. In addition, the electricity price trend will also raise the public's green awareness. When non-renewable energy is exhausted, it is imperative to use renewable energy for power generation, and this will result in the highest electricity prices during peak hours. Realizing the reasons behind the electricity price trend, an intrinsic perception of green awareness among the public may possibly increase. The PS acts as a moderator between PU and PEOU, and has a significant effect on the model fit. Further, green awareness played the role of mediator between PU and AT, and this resulted in highly mediated results. The model fits of PU and PEOU are both positively affected by PS. Products that are sufficiently safe will greatly influence consumers' PU and PEUO, which will lead to consumers' purchasing behavior. Moreover, green awareness has a mediating effect between PU and AT. The results of this study revealed that PU will positively increase consumers' green awareness, and will further affect their AT solar power equipment. The findings and results of SEM provided many important insights regarding consumers' purchasing behavior toward building-attached photovoltaic equipment (BAPV equipment). Firstly, the study found out that consumers' awareness of solar power devices is severely inadequate. Few people believed that this equipment is easy to use, which caused a lack of purchasing behavior. Although PEOU could be found in a few consumers, these consumers were not willing to purchase this equipment. Furthermore, consumers may be unfamiliar with the BAPV system, or they may be put off by the prices of the equipment. Lastly, the public may not be aware of the correlation between the ban on nuclear energy and a foreseeable electricity shortage. Thus, they may not realize that there is a need to use solar power equipment in order to combat the electricity shortage.

In short, it is of utmost urgency to raise the perceived usefulness, perceived ease of use, and perceived safety among the public. To encourage and promote the use of solar power equipment, we have the following six suggestions for the government: (1) conduct face-to-face symposiums to help resolve public queries and confusion; (2) set up solar household demonstration areas and provide subsidies and rewards; (3) educate local area representatives so that they can inform their residents of the benefits of solar equipment; (4) cooperate with solar technology companies to provide hands-on classes and teach the public how to maintain the equipment; (5) publish educational manuals and documents to promote greater awareness; and (6) shoot TV/web announcements of public interest (APIs) to promote the benefits of installing solar power equipment. Additionally, solar technology companies can further improve the ease of use and safety of their products so that consumers will be more confident in using the solar power equipment. In conclusion, the hypothesized model was found to be well constructed. Based on previous studies and theories, this model is able to explain and predict consumers' behavior. Many factors are found to influence consumers' intention to purchase. Thus, solar technology companies and the government need to pay attention to consumer demand if they wish to increase consumers' purchasing intention and behavior.

There were a few limitations that may affect the current study. First, the data was collected only from the northern cities of Taiwan. Even though the original plan was to include all of the cities in 
Taiwan, the final number of questionnaires that were collected failed to reach the number of acceptable samples. Thus, future researchers could attempt to expand the scope and area of collection to include all of the cities in Taiwan. Secondly, this study only focused on BAPV and rooftop generation power systems. In future, other types of building-façade power generation systems, such as BIPV, can be included. Thirdly, this study did not address all of the potential variables, such as the range of prices that consumers are willing to pay, and the level of government grant/subsidies. Future research can take these variables into consideration in their exploration of the factors affecting consumer purchasing behavior. Lastly, this study assumed that consumers installed this solar power generation equipment willingly. However, for the sake of a sustainable future, there is a greater possibility and urgency to adopt renewable energy. Thus in this case, future researchers may need to re-look at consumers' intention toward using and the role of the government. In addition, for some quantitative research, the Conjoint model and contingent valuation method (CVM) can be considered for applications.

Author Contributions: The research was designed by R.C.T. and Y.H.L. administered field survey and collected data. Both of the authors contributed to data analysis and their interpretation. The first draft was written by R.C.T. Revisions and the final draft were completed by R.C.T.

Funding: This research was funded by the National University of Singapore Humanities \& Social Sciences Seed Fund grant number MOST 103-2221-E-032-018-.

Acknowledgments: We acknowledge Tamkang University for their support of this study.

Conflicts of Interest: The authors declare no conflict of interest. The funders had no role in the design of the study; in the collection, analyses, or interpretation of data; in the writing of the manuscript, and in the decision to publish the results.

\section{References}

1. Sommerkorn, M.; Hassol, S.J. Arctic Climate Feedbacks: Global Implications; World Wide Fund for Nature: Godalming, UK, 2009.

2. United Nations High Commissioner for Refugees [UNHCR], World at War: UNHCR Global Trends of Forced Displacement in 2014. 2015. Available online: http:/ / www.unhcr.org/556725e69.pdf (accessed on 22 February 2017).

3. Keane, D. The environmental causes and consequences of migration: A search for the meaning of environmental refugees. Georget. Int. Environ. Law Rev. 2003, 16, 209-223.

4. Lehne, J.; Blyth, W.; Lahn, G.; Bazilian, M.; Grafham, O. Energy services for refugees and displaced people. Energy Strategy Rev. 2016, 13, 134-146. [CrossRef]

5. Biermann, F.; Boas, I. Preparing for a warmer world: Towards a global governance system to protect climate refugees. Glob. Environ. Politics 2010, 10, 60-88. [CrossRef]

6. Kraemer, R.A.; Mutanga, S.S.; Pophiwa, N.; Fetzek, S.; McGlade, K.; Schraven, B.; Khasru, S.M. Building Global Governance for Climate Refugees. 2017. Available online: http://www.g20-insights.org/ (accessed on 15 March 2017).

7. United Nations Environment Program [UNEP]. The Guidelines for National Waster Management Strategies: Moving from Challenges to Opportunities. 2013. Available online: http:/ / cwm.unitar.org/national-profiles/ publications/cw/wm/UNEP_UNITAR_NWMS_English.pdf (accessed on 15 March 2017).

8. Environmental Protection Administration of Taiwan. GHG Emissions Statistics. 2014. Available online: http: / / www.epa.gov.tw / ct.asp?xItem=10052\&ctNode=31352\&mp=epa (accessed on 15 March 2017).

9. Lidskog, R.; Elander, I. Reinterpreting locational conflicts: NIMBY and nuclear waste management in Sweden. Policy Politics 1992, 20, 1-16. [CrossRef]

10. Frantál, B.; Malý, J. Close or renew? Factors affecting local community support for rebuilding nuclear power plants in the Czech Republic. Energy Policy 2017, 104, 134-143. [CrossRef]

11. Roh, S.; Kim, D. The factors of nuclear energy public acceptance and relative importance (public acceptance factors and relative importance). Energy Sources Part B Econ. Plan. Policy 2017, 12, 559-564. [CrossRef] 
12. United Nations Environment Program [UNEP]. Green Economy and Trade-Trends, Challenges and Opportunities. 2013. Available online: https://www.google.com/url?q=http://web.unep. org/greeneconomy/sites/unep.org.greeneconomy/files/field/image/fullreport.pdf (accessed on 18 March 2017).

13. Bureau of Energy, Ministry of Economic Affairs. Million Solar Rooftop PVs. 2012. Available online: http: //web3.moeaboe.gov.tw/ECW / english/content/Content.aspx?menu_id=1761 (accessed on 18 March 2017).

14. Bureau of Energy, Ministry of Economic Affairs. Regulations on the Management of Renewable Energy Power Generation Equipment. 2015. Available online: http:/ / web3.moeaboe.gov.tw/ECW/populace/Law/ Content.aspx?menu_id=1096 (accessed on 18 March 2017).

15. Leccisi, E.; Raugei, M.; Fthenakis, V. The Energy and environmental performance of ground-mounted photovoltaic systems-A timely update. Energies 2016, 9, 622. [CrossRef]

16. Davis, F.D. Perceived usefulness, perceived ease of use, and user acceptance of information technology. MIS Q. 1989, 13, 319-340. [CrossRef]

17. Fishbein, M.; Ajzen, I. Belief, Attitude, Intention, and Behavior: An Introduction to Theory and Research; Addison Wesley: Reading, MA, USA, 1977.

18. Fishbein, M.; Ajzen, I. Predicting and Changing Behavior: The Reasoned Action Approach; Taylor Francis: New York, NY, USA, 2011.

19. Ajzen, I. From intentions to actions: A theory of planned behavior. In Action Control: From Cognition to Behavior; Kuhl, J., Beckman, J., Eds.; Springer: Berlin, Germany, 1985; pp. 11-39.

20. Igbaria, M.; Guimaraes, T.; Davis, G.B. Testing the determinants of microcomputer usage via a structural equation model. J. Manag. Inf. Syst. 1995, 11, 87-114. [CrossRef]

21. Dulany, D.E. Hypotheses and habits in verbal operant conditioning. J. Abnorm. Soc. Psychol. 1961, 63, 251-263. [CrossRef] [PubMed]

22. Dulany, D.E. Awareness, rules, and propositional control: A confrontation with SR behavior theory. In Verbal Behavior and General Behavior Theory; Dixon Deryck Horton, T., Ed.; Prentice-Hall: Upper Saddle River, NJ, USA, 1968.

23. Ajzen, I. The theory of planned behavior. Organ. Behav. Hum. Decis. Process. 1991, 50, 179-211. [CrossRef]

24. Ajzen, I.; Madden, T.J. Prediction of goal-directed behavior-attitudes, intentions, and perceived behavioral-control. J. Exp. Soc. Psychol. 1986, 22, 453-474. [CrossRef]

25. Bandura, A. Self-efficacy: Toward a unifying theory of behavioral change. Psychol. Rev. 1977, 84, $191-215$. [CrossRef] [PubMed]

26. Bandura, A. Self-efficacy mechanism in human agency. Am. Psychol. 1982, 37, 122-147. [CrossRef]

27. Venkatesh, V.; Davis, F.D. A theoretical extension of the technology acceptance model: Four longitudinal field studies. Manag. Sci. 2000, 46, 186-204. [CrossRef]

28. Venkatesh, V.; Morris, M.G.; Davis, G.B.; Davis, F.D. User acceptance of information technology: Toward a unified view. MIS Q. 2003, 27, 425-478. [CrossRef]

29. Fathema, N.; Shannon, D.; Ross, M. Expanding the technology acceptance model (TAM) to examine faculty use of learning management systems (LMSs) in higher education institutions. MERLOT J. Online Learn. Teach. 2015, 11, 210-232.

30. Mohammadi, H. Factors affecting the e-learning outcomes: An integration of TAM and IS success model. Telemat. Inform. 2015, 32, 701-719. [CrossRef]

31. Chuah, S.H.W.; Rauschnabel, P.A.; Krey, N.; Nguyen, B.; Ramayah, T.; Lade, S. Wearable technologies: The role of usefulness and visibility in smartwatch adoption. Comput. Hum. Behav. 2016, 65, $276-284$. [CrossRef]

32. Kardooni, R.; Yusoff, S.B.; Kari, F.B. Renewable energy technology acceptance in Peninsular Malaysia. Energy Policy 2016, 88, 1-10. [CrossRef]

33. Hung, S.Y.; Liang, T.P.; Chang, C.M. A meta-analysis of empirical research using TAM. J. Inf. Manag. 2005, 12, 211-234.

34. Conner, M.; Armitage, C.J. Extending the theory of planned behavior: A review and avenues for further research. J. Appl. Soc. Psychol. 1998, 28, 1429-1464. [CrossRef]

35. Amaro, S.; Duarte, P. An integrative model of consumers' intentions to purchase travel online. Tour. Manag. 2015, 46, 64-79. [CrossRef]

36. Jacoby, J.; Kyner, D.B. Brand loyalty vs. repeat purchasing behavior. J. Market. Res. 1973, 10, 1-9. [CrossRef] 
37. Nunkoo, R.; Juwaheer, T.D.; Rambhunjun, T. Applying the extended technology acceptance model to understand online purchase behavior of travelers. In Proceedings of the 21st International Business Research Conference, Toronto, ON, Canada, 10-11 June 2013.

38. Tae, W.S.; Kim, S.S.; Lee, K.U.; Nam, E.C.; Kim, K.W. Validation of hippocampal volumes measured using a manual method and two automated methods (FreeSurfer and IBASPM) in chronic major depressive disorder. Neuroradiology 2008, 50, 569-581. [CrossRef] [PubMed]

39. Lin, J.C.C.; Lu, H. Towards an understanding of the behavioural intention to use a web site. Int. J. Inf. Manag. 2000, 20, 197-208.

40. Legris, P.; Ingham, J.; Collerette, P. Why do people use information technology? A critical review of the technology acceptance model. Inf. Manag. 2003, 40, 191-204. [CrossRef]

41. Seddon, P.B. A respecification and extension of the DeLone and McLean model of IS success. Inf. Syst. Res. 1997, 8, 240-253. [CrossRef]

42. Iacobici-Luca, N.; Frigura-Iliasa, F.M.; Vatau, D.; Andea, P. Power quality assessment system for a 220 kV/110 $\mathrm{kV}$ high voltage power station. In Proceedings of the Electric Power Quality and Supply Reliability (PQ), Tallinn, Estonia, 29-31 August 2016; pp. 267-272. [CrossRef]

43. Cano-Plata, E.A.; Jimenez-Lozano, G.; Soto-Marín, O.J.; Ustariz-Farfán, A.J.; Wilches, J.A.O.; Arcila, M.C.C.; Estrada, J.H. Hybrid simulation of power quality assessment: An application for power ground grid in arc furnace systems. IEEE Trans. Ind. Appl. 2016, 52, 2648-2653. [CrossRef]

44. DeLone, W.H.; McLean, E.R. Information systems success: The quest for the dependent variable. Inf. Syst. Res. 1992, 3, 60-95. [CrossRef]

45. Delone, W.H.; McLean, E.R. The DeLone and McLean model of information systems success: A ten-year update. J. Manag. Inf. Syst. 2003, 19, 9-30.

46. Intergovernmental Panel on Climate Change (IPCC). Global Warming of $1.5^{\circ} \mathrm{C}$ Report. Available online: http:/ /ipcc.ch/report/sr15/ (accessed on 26 March 2017).

47. Environmental Protection Agency (EPA). Overview of Climate Change Science. 2017. Available online: https: / / www.epa.gov/climate-change-science/overview-climate-change-science (accessed on 26 March 2017).

48. Saboori, B.; Sulaiman, J.; Mohd, S. Economic growth and $\mathrm{CO}_{2}$ emissions in Malaysia: A cointegration analysis of the environmental Kuznets curve. Energy Policy 2012, 51, 184-191. [CrossRef]

49. United Nations Framework Convention on Climate Change [UNFCCC]. Copenhagen Climate Change Conference. 2009. Available online: http://unfccc.int/meetings/copenhagen_dec_2009/meeting/6295.php (accessed on 3 April 2017).

50. Alam, M.; Akram, D.; Sharmin, E.; Zafar, F.; Ahmad, S. Vegetable oil based eco-friendly coating materials: A review article. Arab. J. Chem. 2014, 7, 469-479. [CrossRef]

51. Boztepe, A. Green marketing and its impact on consumer buying behavior. Eur. J. Econ. Political Stud. 2012, 5, 5-21.

52. Khan, S.N.; Mohsin, M. The power of emotional value: Exploring the effects of values on green product consumer choice behavior. J. Clean. Prod. 2017, 150, 65-74. [CrossRef]

53. Sangroya, D.; Nayak, J.K. Factors influencing buying behaviour of green energy consumer. J. Clean. Prod. 2017, 151, 393-405. [CrossRef]

54. Rashid, N.R.N.A. Awareness of eco-label in Malaysia's green marketing initiative. Int. J. Bus. Manag. 2009, 4, 132. [CrossRef]

55. Norazah, M.S. Green products purchases: Structural relationships of consumers' perception of Eco-Label, Eco-Brand and environmental advertisement. J. Sustain. Sci. Manag. 2013, 8, 1-10.

56. Rahbar, E.; Abdul Wahid, N. Investigation of green marketing tools' effect on consumers' purchase behavior. Bus. Strategy Ser. 2011, 12, 73-83. [CrossRef]

57. Laroche, M.; Bergeron, J.; Barbaro-Forleo, G. Targeting consumers who are willing to pay more for environmentally friendly products. J. Consum. Market. 2001, 18, 503-520. [CrossRef]

58. Han, H.; Hsu, L.T.J.; Sheu, C. Application of the theory of planned behavior to green hotel choice: Testing the effect of environmental friendly activities. Tour. Manag. 2010, 31, 325-334. [CrossRef]

59. Tan, L.P.; Johnstone, M.L.; Yang, L. Barriers to green consumption behaviours: The roles of consumers' green perceptions. Australas. Market. J. (AMJ) 2016, 24, 288-299. [CrossRef]

60. Lichtenstein, D.R.; Bloch, P.H.; Black, W.C. Correlates of price acceptability. J. Consum. Res. 1988, 15, $243-252$. [CrossRef] 
61. Parguel, B.; Delécolle, T.; Valette-Florence, P. How price display influences consumer luxury perceptions. J. Bus. Res. 2016, 69, 341-348. [CrossRef]

62. Shirai, M. Effects of price reframing tactics on consumer perceptions. J. Retail. Consum. Serv. 2017, 34, 82-87. [CrossRef]

63. Dodds, W.B.; Monroe, K.B. The effect of brand and price information on subjective product evaluations. NA-Adv. Consum. Res. 1985, 12, 85-90.

64. Lin, J.; Lobo, A.; Leckie, C. The role of benefits and transparency in shaping consumers' green perceived value, self-brand connection and brand loyalty. J. Retail. Consum. Serv. 2017, 35, 133-141. [CrossRef]

65. Lovelock, C.H. Services Marketing: People, Technology, Strategy, 4th ed.; Prentice Hall International: New York, NY, USA, 2001.

66. Yu, J.; Lee, H.; Ha, I.; Zo, H. User acceptance of media tablets: An empirical examination of perceived value. Telemat. Inform. 2015, 34, 206-223. [CrossRef]

67. Zeithaml, V.A. Consumer perceptions of price, quality, and value: A means-end model and synthesis of evidence. J. Market. 1988, 52, 2-22. [CrossRef]

68. Grewal, D.; Monroe, K.B.; Krishnan, R. The effects of price-comparison advertising on buyers' perceptions of acquisition value, transaction value, and behavioral intentions. J. Market. 1998, 62, 46-59. [CrossRef]

69. Hänninena, N.; Karjaluotoa, H. Environmental values and customer-perceived value in industrial supplier relationships. J. Clean. Prod. 2017, 156, 604-613. [CrossRef]

70. Taylor, S.; Todd, P.A. Understanding information technology usage: A test of competing models. Inf. Syst. Res. 1995, 6, 144-176. [CrossRef]

71. Dunlap, R.E.; Liere, K.D.V.; Dillman, D.A. Evidence of decline in public concern with environmental quality: A reply. Rural Sociol. 1979, 44, 204-212.

72. Petrick, J.F. Development of a multi-dimensional scale for measuring the perceived value of a service. J. Leis. Res. 2002, 34, 119. [CrossRef]

73. Hair, J.F.; Black, W.C.; Babin, B.J.; Anderson, R.E.; Tatham, R.L. Multivariate Data Analysis, 6th ed.; Pearson Prentice Hall: Upper Saddle River, NJ, USA, 2006.

74. Directorate-General of Budget Accounting and Statistics (DGBAS). Report on the Survey of Family Income Expenditure. 2014. Available online: http://win.dgbas.gov.tw/fies/a11.asp?year=103 (accessed on 4 April 2017).

75. Anderson, J.C.; Gerbing, D.W. Structural equation modeling in practice: A review and recommended two-step approach. Psychol. Bull. 1988, 103, 411. [CrossRef]

76. Peterson, R.A. A meta-analysis of cronbach's coefficient alpha. J. Consum. Res. 1994, 21, 381-391. [CrossRef]

77. Bollen, K.A. A new incremental fit index for general structural equation models. Sociol. Methods Res. 1989, 17, 303-316. [CrossRef]

78. Bentler, P.M.; Wu, E.J. EQS-Windows User's Guide, version 4; BMDP Statistical Software: Los Angeles, CA, USA, 1993.

79. Jöreskog, K.G.; Sörbom, D. LISREL 7: A Guide to the Program and Applications; SPSS: Chicago, IL, USA, 1989.

80. Fornell, C.; Larcker, D.F. Evaluating structural equation models with unobservable variables and measurement error. J. Market. Res. 1981, 18, 39-50. [CrossRef]

81. Bagozzi, R.P.; Yi, Y. On the evaluation of structural equation models. J. Acad. Market. Sci. 1988, 16, 74-94. [CrossRef]

82. Gode, D.K.; Sunder, S. Allocative efficiency of markets with zero-intelligence traders: Market as a partial substitute for individual rationality. J. Political Econ. 1993, 101, 119-137. [CrossRef]

83. Jha, S.K.; Puppala, H. Prospects of Renewable Energy Sources in India: Prioritization of Alternative Sources in Terms of Energy Index. Energy 2017, 127, 116-127. [CrossRef]

84. Niu, D.X.; Song, Z.Y.; Xiao, X.L. Electric power substitution for coal in China: Status quo and SWOT analysis. Renew. Sustain. Energy Rev. 2017, 70, 610-622. [CrossRef]

85. Tsoutsos, T.; Frantzeskaki, N.; Gekas, V. Environmental impacts from the solar energy technologies. Energy Policy 2005, 33, 289-296. [CrossRef]

(C) 2018 by the authors. Licensee MDPI, Basel, Switzerland. This article is an open access article distributed under the terms and conditions of the Creative Commons Attribution (CC BY) license (http:/ / creativecommons.org/licenses/by/4.0/). 